\title{
Reviewing Fire Disasters at Traditional Markets: Causes, Impacts, and Remedies
}

\author{
Jati Utomo Dwi Hatmoko ${ }^{1}$, Dian Sukma Larassati ${ }^{2}$ \\ Department of Civil Engineering, Diponegoro University, Semarang - Indonesia \\ 1jati.hatmoko@ft.undip.ac.id,_dianlarassati@student.undip.ac.id
}

\begin{abstract}
Despite the busy activities of traditional markets, the physical condition and fire protection system of traditional markets are generally poor, making it vulnerable to fire incidents. This study aims to identify and map the causes and impacts of fire incidents on traditional markets in various countries. Data was collected through a systematic literature review from 100 references, with a total of 60 fire incidents at the traditional markets in various countries. The research found that the main causes of traditional market fires were: electricity, negligence, and arson attacks. This study also identified general conditions and problems in traditional markets related to fire incidents, and found 6 vulnerable factors of fire risk, i.e. building, social, institutional, environmental, health, and economic factors, which later mapped in the form of cause and effect diagrams. Based on the research findings, a recommendatio $\mathrm{n}$ on fire prevention strategy for traditional markets is proposed.
\end{abstract}

Keywords: fire disaster, traditional market, vulnerable factors

\section{Introduction}

Traditional markets are one of public buildings that are most vulnerable to fire. In Indonesia, for example, throughout 2015 there were 283 casesof market fires with an estimated loss of Rp. 377 billion. This is a significant increase compared to 2014 of 140 cases with an estimated loss of Rp. 212 billion [1]. Whereas the number of cases in 2019 is lower with 200 cases were recorded [2]. The fire incidents in traditional markets cause loss of lives, damage to environmental and assets, disruption on the production activities, and job losses [3,4]. These incidents also cause psychological distress to the victims [5]. They also demonstrate negative impacts on the economy in various countries, as traditional markets are notably one of the highest contributors to regional income[6].

To maintain the sustainability of traditional markets, it is very important to comprehensively understand the situation, issues, and factors related to the fire incidents, so that lessons can be learned. This study aims to map the causes and impacts of traditional market fires in various countries, as well as to identify the vulnerability factors, so that remedies can be strategically recommended to lower the risks of fire incidents in traditional markets.

\section{Method}

This research was conducted using qualitative approach through a systematic literature review on traditional market fires in various countries, covering both developed and developing countries. 
A comprehensive analysis was carried out based on 100 references related to market fire incidents, consisted of 31 journal papers and 69 news from national and international media to identify the causes, impacts and vulnerability factors of fire incidents at traditional markets. A fish bone diagram was later developed to map the causes and effects of fire incidents in traditional markets.

\section{Results and Discussion}

The followings are the results of the identification of causes and lossesof traditional market fires, existing problems, and vulnerability factors.

\subsection{Causes and losses of traditional market fires}

Learning from 60 cases of fire incidents at the traditionalmarkets in various countries as shown in Tables 1 and 2, in general the fire incidents are mostly caused by electrical faults, negligence and arson attacks, resulting in huge material losses. Other minor causes include gas stoves, smoking, and burning rubbish, all of which are related to activities of the market occupants. In China, $70 \%$ of the fire incidents were suspected to be caused by electrical faults, improper use of fire in daily life, smoking, and ignorance of fire safety regulations [7]. China's Yuquan Furniture Shopping Centrecaught fire in 1998 due to an electrical fault with an estimated loss of 20.88 million yuan [7].

The main factor causing traditional market fires in Korea was also related to electricity. The Seomun Daegu market fire in 2016 was caused by electrical faults, as the high use of electric heating equipment during cold weather increases the risk of fire [8]. In addition, the market buildings that were more than 20 years old are more prone to fire, the distance between shops was close, and the selection of building materials or types of goods sold causes the fire to spread rapidly. The estimated total losses due to traditional market fires in Korea in the past five years have been around 13.36 million won [8]. As for the Kumasi Central market in Ghana, possible factors of fire in 2009-2012 include power fluctuations $26.32 \%$, cooking with naked fire in the market $18.95 \%$, overloading of electrical appliance $15.79 \%$, improper and old electrical wiring system $12.63 \%$, illegal tapping of electrical power from the national grid $10.52 \%$, use of substandard electrical materials $8.42 \%$, and use of defective generators $7.37 \%[9,10]$.

In Kolkata, India, fire incidents in Nandaram Market in 2008 were caused by electrical faults with estimated losses of Rs 600 crore, whereas in 2013 the Surya Sen Market fires were caused by electrical short circuits [11]. In 2018 Bagree Market caught fire with an estimated loss of ₹ 20-25 crore and no known cause of fire [12]. In 2018 the Siliguri Bidhan Market, India fire was caused by an electrical short circuit [13]. Gariahat Market caught fire in 2019 caused by electrical short circuits [14]. Whereas the Jankara Market fire in Nigeria in 2012 was caused by fireworks [15]. Abubakar Rimi Market and Birnin Kebbi Central Market caught fire in 2016 caused by electrical faults [16].

Table 1. Some examples of fire disasters of traditional markets globally

\begin{tabular}{cccccc}
\hline Fire disaster & Year & Location & Estimated loss & Cause of fire & Ref \\
\hline Yuquan Furniture Shopping & 1998 & China & 20,88 million yuan & Electrical fault & {$[7]$} \\
Center & & & & & - \\
Seomun Daegu Market & 2005 & Korea & 168,9 billion won & Gas heater & {$[8]$} \\
Camden Canal Market & 2008 & UK & $£ 30$ million & Electrical fault & {$[17]$} \\
Nandaram Market & 2008 & India & Rs 600 crore & $19]$
\end{tabular}




\begin{tabular}{|c|c|c|c|c|c|}
\hline Fire disaster & Year & Location & Estimated loss & Cause of fire & Ref \\
\hline Kumasi Central Market & 2009 & Ghana & - & Electrical fault and negligence & {$[9,10]$} \\
\hline Kumasi Central Market & 2010 & Ghana & - & Electrical fault and negligence & {$[9,10]$} \\
\hline Kumasi Central Market & 2012 & Ghana & - & Electrical fault and negligence & {$[9,10]$} \\
\hline $\begin{array}{c}\text { Super Suwedru Melcom } \\
\text { Market }\end{array}$ & 2012 & Ghana & - & - & {$[20]$} \\
\hline Jankara Market & 2012 & Nigeria & - & Fireworks or firecrackers & {$[15]$} \\
\hline Surya Sen Market & 2013 & India & - & Electrical short circuit & {$[21]$} \\
\hline Chatucak Market & 2013 & Thailand & 20 million baht & Electrical short circuit & {$[22]$} \\
\hline Camden Stables Market & 2014 & England & - & - & {$[23]$} \\
\hline Sango Plank Market & 2015 & Nigeria & $\mathrm{N} 250$ million & - & {$[24]$} \\
\hline Seomun Daegu market & 2016 & Korea & - & Electrical fault & {$[8]$} \\
\hline Jurong West Market & 2016 & Singapore & $\$ 6$ million & Arson attack & {$[25]$} \\
\hline Abubakar Rimi Market & 2016 & Nigeria & $\mathrm{N} 2$ trillion & Electrical fault & {$[16]$} \\
\hline $\begin{array}{c}\text { Birnin Kebbi Central } \\
\text { Market }\end{array}$ & 2016 & Nigeria & - & Electrical fault & [16] \\
\hline Tsukji Fish Market & 2017 & Japan & - & - & {$[26]$} \\
\hline Sunrise Oriental Market & 2017 & US & $\$ 250,000$ & - & {$[27]$} \\
\hline Mercado Oriental Market & 2017 & Nicaragua & - & - & {$[28]$} \\
\hline Camden Lock Market & 2017 & England & - & - & [29] \\
\hline Seremban Market & 2017 & Malaysia & RM6 million & Arson attack & {$[30]$} \\
\hline Bagree Market & 2018 & India & $₹ 20-25$ crore & - & {$[12]$} \\
\hline Siliguri Bidhan Market & 2018 & India & - & Electrical short circuit & {$[13]$} \\
\hline Sango Plank Market & 2018 & Nigeria & - & Arson attack & {$[31]$} \\
\hline Gariahat Market & 2019 & India & - & Electrical short circuit & [14] \\
\hline La Merced Market & 2019 & Mexico & - & Electrical fault & {$[32]$} \\
\hline Odawna Market & 2019 & Ghana & - & Electrical fault & [33] \\
\hline Sentul Market & 2019 & Malaysia & - & - & [34] \\
\hline Kalibo Public Market & 2019 & Philippines & P35 million & Electrical wiring & {$[35]$} \\
\hline
\end{tabular}

Similarly, traditionalmarket fires in Indonesia were mostly caused by electricity, negligence and arson attacks (Table 2). Gede Bage market in Bandung has experienced fire incidents three times in the last five years. In 2015 it was caused by an electrical fault with estimated losses of 19.4 billion rupiah [36, 37], then in 2018 two incidents due to electrical faults with estimated losses of 6 billion rupiahs and burning garbage with estimated losses of 4.5 billion rupiah $[38,39,40]$. The Johar Market fire of Semarang in 2015 was caused by an electrical fault with an estimated loss of 350 billion rupiah [41]. The unavailability of fire protection systems, unclear merchant zones arrangement, and lack of residents' awareness of fire hazards make the Bandung Andir Market vulnerable to fire hazards [42]. Similar to the Market in Malang, the unavailability of a fire protection system, lack of awareness of visitors and the messy arrangement of stal are the cause of the market being vulnerable to fire hazards [43]. Turi Market fire in 2012 caused huge losses to traders, it was not equipped with a fire protection system, so the fire quickly spread [44].

Table 2. The fire disasters of traditional markets in Indonesia

\begin{tabular}{cccccc}
\hline Fire disaster & Year & Location & Estimated loss & Cause of fire & Ref \\
\hline Gede Bage market & 2015 & West Java & 19,4 billion rupiah & Electrical fault & {$[36,37]$} \\
Caringan market & 2015 & West Java & 5 billion rupiah & Electrical fault & {$[45]$} \\
Pelita market & 2015 & West Java & 20 billion rupiah & Electrical fault & {$[46]$} \\
Johar market & 2015 & Central Java & 350 billion rupiah & Electrical fault & {$[41]$} \\
Kebayoran Lama market & 2017 & Jakarta & 1 billion rupiah & Electrical fault & {$[47]$} \\
Karamat Jati market & 2017 & Jakarta & 9 billion rupiah & Electrical fault & {$[47,48]$} \\
Sorowako market & 2017 & Sulawesi & 5 billion rupiah & Electrical fault & {$[49,50]$} \\
& \multirow{5}{*}{ Selatan } & Yogyakarta & 475 million rupiah & Gas stove canister & {$[51,52]$}
\end{tabular}




\begin{tabular}{cccccc}
\hline Fire disaster & Year & Location & Estimated loss & Cause of fire & Ref \\
\hline Bukittinggi market & 2017 & Sumatera Barat & 1,5 trillion rupiah & Electrical fault & {$[53]$} \\
Pasrepan market & 2017 & East Java & 1,6 billion rupiah & Electrical fault & {$[54,55]$} \\
Gede Bage market & 2018 & West Java & 6 billion rupiah & Electrical fault & {$[38,39]$} \\
Gede Bage market & 2018 & West Java & 4,5 billion rupiah & Burning garbage & {$[40]$} \\
Wiradesa market & 2018 & Central Java & 7 billion rupiah & Electrical fault & {$[56]$} \\
Boom Lama market & 2018 & Central Java & 50 million rupiah & Electrical short circuit & {$[41]$} \\
Malaka market & 2019 & Jakarta & 50 million rupiah & Electrical fault & {$[57]$} \\
Eviles market & 2019 & Jakarta & 500 million rupiah & Burning garbage & {$[58]$} \\
Lawang market & 2019 & East Java & 9 billion rupiah & Electrical fault & {$[59]$} \\
Patemon market & 2019 & Central Java & 11 million rupiah & Electrical fault & {$[60]$} \\
Kosambi market & 2019 & West Java & 20 billion rupiah & Electrical fault & {$[61]$} \\
Nglangon market & 2019 & Central Java & 1 billion rupiah & Electrical fault & {$[62]$} \\
Mungkid market & 2019 & Central Java & 3 billion rupiah & Electrical fault & {$[63]$} \\
Ngunut market & 2019 & East Java & 80 billion rupiah & Arson attack & {$[64]$} \\
Baros market & 2019 & West Java & 10 billion rupiah & Smoke & {$[65]$} \\
Bendul Merisi market & 2019 & East Java & 30 million rupiah & Burning garbage & {$[66]$} \\
Guntur Ciawitali Blok D & 2019 & West Java & 300 million rupiah & Electrical fault & {$[67]$} \\
market & & & & & {$[41]$} \\
Jatingaleh market & 2019 & Central Java & 20 million rupiah & Electrical short circuit & {$[41]$} \\
Kedungmundu market & 2019 & Central Java & 300 million rupiah & Gas stove canister & {$[41]$} \\
Porda Juwana market & 2020 & Central Java & 2 billion rupiah & Electrical fault & {$[68,69]$} \\
Way Jepara market & 2020 & Lampung & 2,5 billion rupiah & Electrical fault & {$[70,71]$} \\
Lodoyo market & 2020 & East Java & 150 million rupiah & Electrical fault & {$[72]$} \\
\hline
\end{tabular}

\subsection{Existing conditions and inhibiting factors in the traditional market fire}

The unavailability of fire protection systems and the lack of knowledge of market occupants of the use of fire extinguishers are factors that inhibit the evacuation process and cause fires to spread rapidly [7, 9, 42, 43, 77, 81]. The unavailability of accesspoints for firefighters and poor road conditions, as well as poor performance of active and passive protection systems have causedthe evacuation process of victims to be hampered in the event of a fire $[8,9$, $10,43,73,77,81]$. Whereas the function and performance of building facilities are a benchmark for the design stages of a building in preventing and overcoming fire hazards $[74,80]$. The surrounding conditions of traditional markets, such as illegal vehicle parking and traders selling outside the market are a hindering factor in the process of extinguishing fires $[8,9,10,79]$. In addition, the height of the building and the speed of the wind affect the level of difficulty in the process of extinguishing the fire. The higher the building, the time needed for the evacuation of occupants the longer, and the height of the building serves as a determinant of the fire protection system that will be used from a building $[75,76,78,80,82]$. Arrangement of traders according to the type of goods sold and the wet or dry zone reduce the risk s of fire and facilitate the evacuation process $[42,43,78]$.

\subsection{Vulnerability factors of traditional markets to fire risk}

Traditional markets have a high level of activity and complexity that causes vulnerability to fire disasters. In this case, vulnerability is defined as pre-disaster condition that has the potential to become a disaster when it encounters danger. The vulnerability factors can be classified into building, social, institutional, environmental, health and economic (Table 4). Building factors include the age of the building, the narrow fire extinguisher access point, the use of electric heaters, and damage to goods stored on the market [8]. Distances between buildings and fire protection systems that do not function properly have the potential to pose a risk of fire [77]. The 
number of floors, the use of flammable building materials, and the unavailability of fire communication tools affect the occupant's evacuation process and slow down information to residents in the event of a fire [83].The social factors are associated with occupant activities, the occupant densities and the lack of knowledge of the dangers of fire and safety procedures [8, $80]$, including the use of cooking equipment on the market and illegal connection of cables increase the risk of fire [10].

Table 3. Vulnerability factors of traditional markets to fire risk

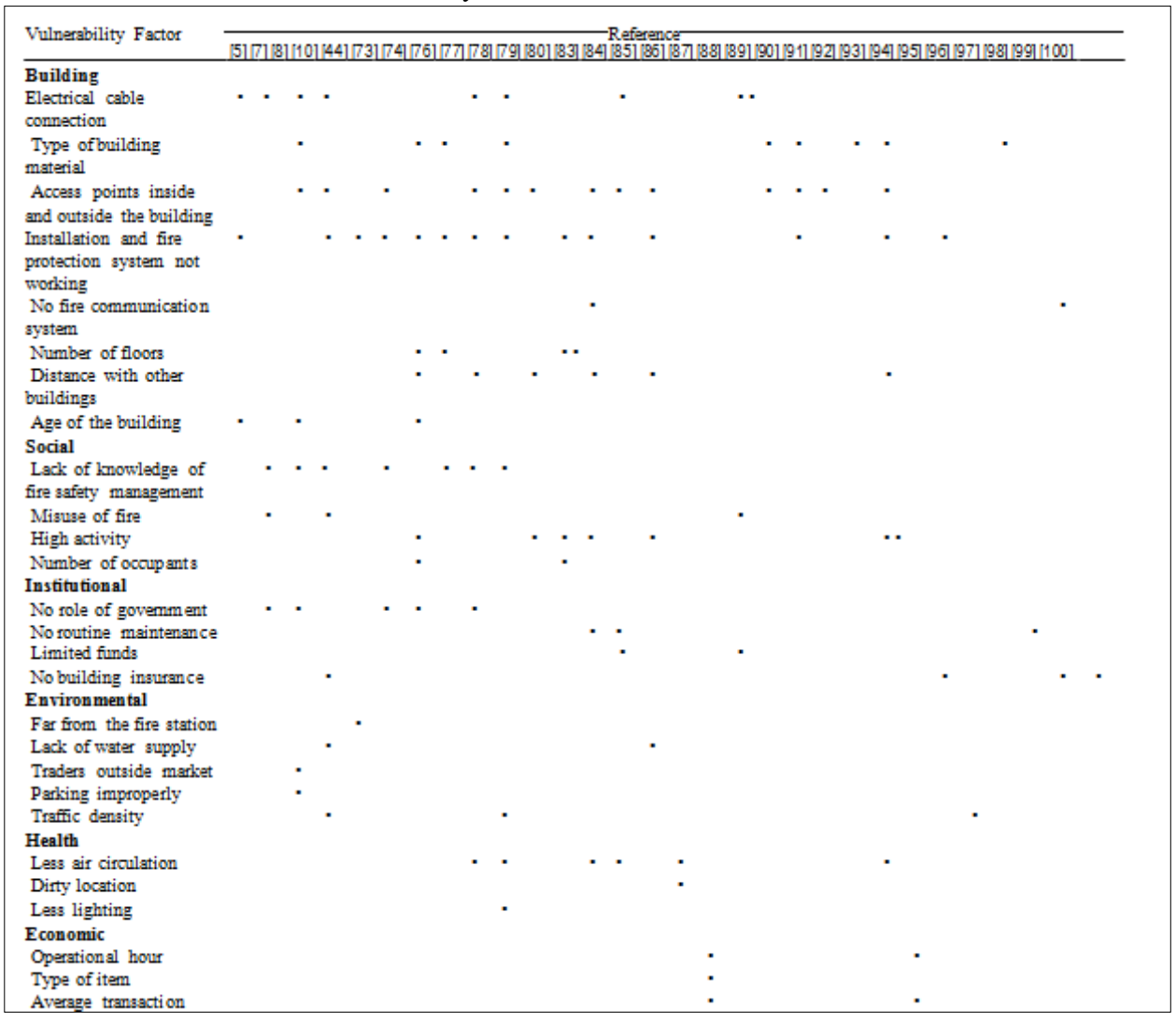

Institutional vulnerability factor is related to the role of government as typically the owner of traditionalmarkets in the implementation and control of routine maintenance of market buildings and the availability of costs [84]. As the traditional markets are considered vulnerable to risk of fire, building insurance is required as a form of protection, and this needs an understanding of insurance of the relevant party [10]. Environmental factors are associated with surrounding conditions of the market, including street vendors and illegal vehicle parking [8]. The distance of the fire brigade station to the market influences the time travel of the firefighters to the location, as once occurred in Turi marketin Surabaya, in which fire was rapidly spreading as thefire fighters arrived late [44]. In addition, the high traffic density surrounding the market may also cause congestion, thus affecting the time travel of the fire fighters to reach the market location [10]. The unavailability of fire extinguishers and the lack of local water sources can inhibit the process of extinguishing the fire [85]. The health factors are associated with health requirements, such as the availability of air circulation in the market buildingand a clean location [86]. Poor ventilation is 
one of the causes of a fire, as the room becomes humid, making it more vulnerable to fire [78]. Economic factors include market operating time and types of goods sold, which affect the average transaction value. The higher the average transaction value indicates the higher trading activities in the market, thus reflecting higher risks of fire incidents [87]. Figure 1 shows the map of causal relationship of the six vulnerability factors identified above.

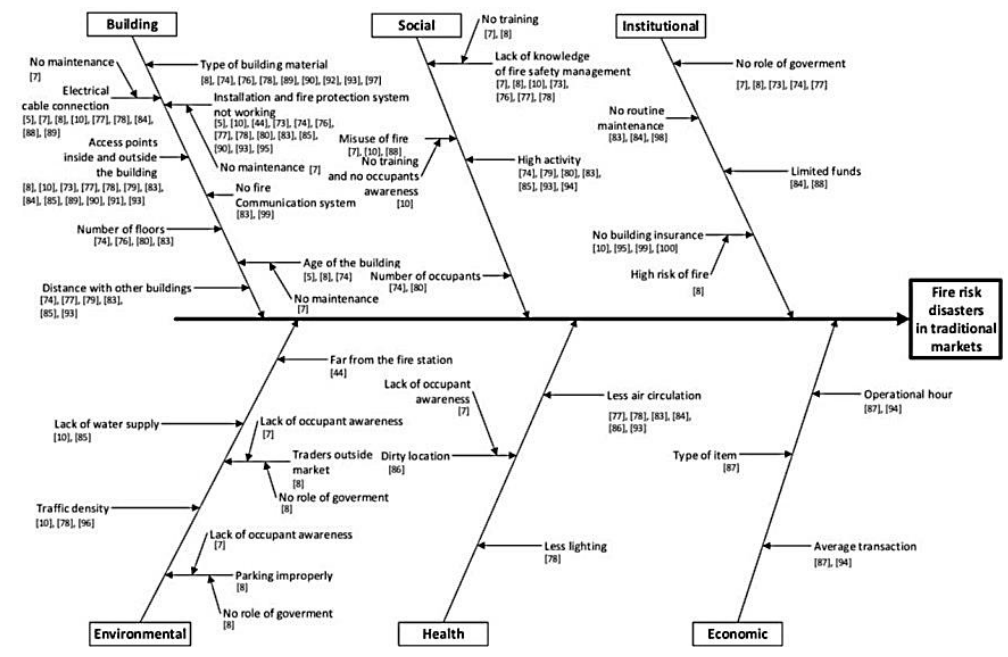

Fig.1. Cause and effect diagram of fire disaster of traditional markets

\subsection{Strategies to minimize the vulnerability factors of traditional market fires}

To reduce the fire incidents in traditional markets, prevention strategies can be formulated based on the identified vulnerability factors. In terms of the building factors, remedies can be done by providing an active protection system and a fire communication system that functions properly. Routine maintenance of market building facilities and supported by the government in terms of controland supervision since the planning stage of traditional market buildings.

The social vulnerability factors can be minimized by conducting training on fire safety management and limiting the operating hours of traditional markets to reduce the high number of occupants at a certain time. In relation to the institutional factors, the government is expected to play an active role in the implementation of fire prevention in traditional markets, provide funds for the procurement and maintenance of fire protection systems, and provide building insurance as a form of risk transfer to third parties and asset protection. Minimizing the vulnerability of the environmental factors can be done by providing access to information and facilities to market residents, thereby reducing the level of fire risks and the ease of occupants obtaining information. Ensuring the building's circulation and ventilation in accordance with the regulation, providingand maintaining evacuation routes, gathering points, and cleaning facilities are part of strategies related to the health factors. In relation to the economic factors, the arrangement of trading zones in the market based on the types of goodssold, not only willattract visitor to higher transaction, but also willprovide sufficient access to fire brigades in a case of fire. 


\section{Conclusions}

This research identified 60 casesof traditional market fires in various countries, including Indonesia. Themain causes of traditional market fires were found related to electrical faults, negligence, and arson attacks. The general condition and problems include the unavailability of or non-functioning fire protection systems, the lack of knowledge of market occupants, and the non-ideal surrounding environment. Six traditional market vulnerability factors to fire risk were identified, i.e. building, social, institutional, environmental, health and economic factors, which were mapped with relevant sub factors using fish bone diagram to understand the cause and effect relationship. Strategies were later formulated based on the findings of the vulnerability factors, e.g. the provision of active protection system, routine maintenance, provision of building insurance, etc. The findings of this research are expected to be beneficial for stakeholders of traditional markets in understanding and anticipating fire incidents at traditionalmarketsin the future.

\section{References}

[1] Rahman, N V, Nurdina S, Muhammad D C, and Elsa L N.: Kajian Fasilitas Tangga Darurat Kebakaran Sebagai Sarana Evakuasi pada Pasar Tradisional Bertingkat (The study in the emergency exit facilities fire as a Means of Evacuation at Multilevel Traditional Markets). Proceedings of National Seminar 'Local Wisdom in Diversity for Indonesia's Development', pp. 265-272 (2018)

[2] Lokadata, 2019. Traditional Market. 200 Pasar Tradisional Terbakar Sepanjang 2019 (200 Traditional Market Fire throughout 2019). Available online at https://lokadata.id/artikel/200-pasar-tradisional-terbakar-sepanjang-2019, Accessed on June 13,2020

[3] Pratama, A.: Perancangan Sarana Penyelamat Diri dan Kebutuhan APAR pada Darurat Kebakaran di Kantor Kesehatan Pelabuhan Kelas II Balikpapan (Design of Self-rescue Facilities and APAR Needs in Fire Emergency in Balikpapan Class II Port Health Office). The Indonesian Journal of Occupational Safety and Health. Vol. 5, pp. 21 -30 (2016)

[4] Firdani, L, Ekawati and Bina K.: Analisis Penerapan Alat Pemadam Api Ringan (APAR) Di PT. X Pekalongan (Analysis of the Application of Light Fire Extinguisher (APAR) in PT. X Pekalongan). Jurnal Kesehatan Masyarakat. Vol. 2, pp. 300 -308 (2014)

[5] Fitria, D, Mustikasari M, and Ria U P.: The Psychological Capital and Anxiety Felt by PostMarket Fire Disaster Victims. JURNAL NERS. Vol. 15, pp. 1-6(2020)

[6] Ilodiuba, N, Ify L. N, and John U.: Awareness Assessment of Hazardous Activities and Effects on Market Fire in Nigeria. International Journal of Health, Safety and Environments (IJHSE). Vol. 3, pp. 48 -56 (2017)

[7] Lizhong, Y, Zhou X, Deng Z, Fan W, and Wang Q.: Fire Situation and Fire Characteristic Analysis Based on Fire Statistics of China. Fire Safety Journal. Vol. 37, pp. $785-802$ (2002)

[8] Sangil R, and Juho L.: Analysis and Implications of FIRE Vulnerability in Traditional Markets in Republic of KOREA. International journal of human \& disaster. Vol. 1, pp. 1-4 (2016)

[9] Addai, E K., Samuel K. T, Joe-Steve A., and Isaac Y.: Trend of Fire Outbreaks in Ghana and Ways to Prevent These Incidents. Safety and Health at Work. Vol. 7, pp. 284-292 (2016)

[10] Twum-Barima, L. M.: An Assessment of the Awareness of Fire Insurance in the Informal Sector: A Case Study of Kumasi Central Market in Ghana. International Journal of Humanities Social Sciences and Education. Vol. 1, pp. 41-47 (2014) 
[11] Das, S.: Review of Risk Factors of Construction Site Fire and Suggestions for Its Mitigation . The Asian Review of Civil Engineering. Vol. 2, pp. 13-19(2013)

[12] The Hindu Business Line, 2018. Current Theme: Massive Fire Breaks Out at Bagri Market. Available online at https://www.thehindubusinessline.com/news/massive-firebreaks-out-at-bagri-market/article24961785.ece, Accessed on May 27, 2020

[13] India.com, 2018. West Bengal: Fire Breaks Out in Four Garment Shops in Siliguri's Bidhan Market. Available online at https://www.india.com/news/india/west-bengal-firebreaks-out-in-four-garment-shops-in-siliguri-3456239/, Accessed on May 29, 2020

[14] The Telegraph, 2019. A Failure of The Principles of Urban Living. Available online at https:/www.telegraphindia.com/opinion/calcutta-s-gariahat-market-fire-a-failureof-the-principles-of-urban-living/cid/1682371,

Accessed on May 29, 2020

[15] A.A, Popoola, Adekalu, O. B., Adeleye, B. M., Jiyah, F.: Analysis of Causes and Characteristics of Market Fires in Lagos Stat e, Nigeria. Int'l Journal of Agric. And Rural Dev. Vol. 19, pp. 2407-2421 (2016)

[16] Allafrica.com, 2016. Nigeria: Market Fires Could Be Economic Warfare. Available online at https://allafrica.com/stories/201604030104.html, Accessed on May 28,2020

[17] The Sun, 2017. Blaze Devastation. Camden Market fire - Where is Camden Lock and Which Restaurants, Shops and Bars have been Affected by The Blaze?. Available online at https://www.thesun.co.uk/news/3983677/camden-market-fire-camden-lock-latest/, Accessed on May 27, 2020

[18] India Today, 2008. Deadly Inferno. One of The Worst Fires in The History of Kolkata Shows Norms are being Brazenly Flouted for Commercial Gains and Many Such Disasters are Waiting to Happen. Available online at https://www.indiatoday.in/magazine/states/story/20080128 -deadly-inferno-735172-200801-17, Accessed on May 28, 2020

[19] The Telegraph, 2019. Fire Revisits Nandaram Market, 11 years on. Available online at https://www.telegraphindia.com/states/west-bengal/fire-revisits-nandaram-market11-years-on/cid/1694435, Accessed on May 28, 2020

[20] News Ghana, 2012. Disaster Strikes Another Melcom Supermarket Shop in SouthWestern Ghana. Available online at https://newsghana.com.gh/disaster-strikes-anothermelcom-supermarket-shop-in-south-western-ghana/, Accessed on May 13, 2020

[21] Wikipedia, 2013. 2013 Kolkata Market Fire. Available online at https://en.wikipedia.org/wiki/2013_Kolkata_market_fire, Accessed on May 28, 2020

[22] Bangkok Post, 2013. Fire at Chatuchak Market. Available online at https://www.bangkokpost.com/thailand/politics/349356/fire- hits-chatuchak-marketdamage-put-at-20-million-baht, Accessed on May 29, 2020

[23] BBC News, 2014. Fire Breaks Out at Camden Stables Market, London. Available online at https://www.bbc.com/news/uk-

england-27480113, Accessed on May 30, 2020

[24] New Peak Magazine, 2015. Christmas Disaster! Fire Razes 200 Shops at Ibadan Plank Market. Available online at https://newspeakonline.com/christmas-disaster-fire-razes-200shops-at-ibadan-plank-market/, Accessed on June 1,2020

[25] The Starits Time, 2018. Man Gets 111/2 Years' Jail for Jurong West Market Fire that Led to More than \$6 Million in Damage and Losses. Available online at https://www.straitstimes.com/singapore/courts-crime/man-gets-1112-years-jail-for-jurongwest-market- fire-that-led-to-6-million-in, Accessed on May 15, 2020

[26] BBC News, 2017. Japan's Historic Tsukiji Fish Market Catches Fire. Available online at https://www.bbc.com/news/world-asia- 40817293, Accessed on May 15, 2020

[27] Wbay.com, 2017. Fire Causes $\$ 250 \mathrm{~K}$ in Damage at Sunrise Oriental Market. Available online at https://www.wbay.com/content/news/Fire-causes-250K-in-damage-at-SunriseOriental-Market-441860923.html, Accessed on May 28, 2020 
[28] BBC News, 2017. Nicaragua: Dozens of Shops Lost to Blaze at Traditional Market. Available online at https://www.bbc.com/news/world-latin-america-39917930, Accessed on May 28, 2020

[29] BBC News, 2017. Camden Lock Market Fire: Seventy Firefighters Tackle Blaze. Available online at https://www.bbc.com/news/uk-england-london-40552451, Accessed on May 28, 2020

[30] New Straits Times, 2017. Arson Behind Seremban Main Market Blaze. Available online at https://www.nst.com.my/news/nation/2017/11/300839/arson-behind-seremban-mainmarket-blaze, Accessed on June 1,2020

[31] Concise, 2018. Fire Razes 100 Shops at Ibadan Plank Market. Available online at https://www.concise.ng/2018/01/12/fire-razes- 100-shops-ibadan-plank-market/, Accessed on June 1,2020

[32] Mexico News Daily, 2019. 2 Dead and Over 700 Stands Destroyed in Mexico City Market Fire. Available online at https://mexiconewsdaily.com/news/2-dead-and-over-700-standsdestroyed/, Accessed on May 28,2020

[33] Ghana Web, 2019. Disasters that Wrecked Ghana in 2019. Available online at https://www.ghanaweb.com/GhanaHomePage/NewsArchive/Disasters-that-wrecked Ghanain-2019-805717, Accessed on May 13, 2020

[34] New Straits Time, 2020. Massive Fire Guts Eight Stalls at Iconic Pasar Sentul [NSTTV]. Available online at https://www.nst.com.my/news/nation/2020/01/552432/massive-fire-guts-eight-stalls-iconicpasar-

sentul?utm_source=headtopics\&utm_medium=news\&utm_campaign=2020-01-01, Accessed on June 1, 2020

[35] Sun Star ILOILO, 2019. Kalibo Under State of Calamity After Huge Market Fire. Available online at https://www.sunstar.com.ph/article/1823342, Accessed on June 1, 2020

[36] Tempo, 2015. Pasar Gedebage Kebakaran, Ratusan Pedagang Diungsikan (Gedebage Market Fire, Hundreds of Traders were Evacuated). Available online at https://nasional.tempo.co/read/685129/pasar-gedebage-kebakaran-ratusan-pedagangdiungsikan/full\&view=ok, Accessed on May 10, 2020

[37] Kompas, 2015. Kebakaran Pasar Gedebage, Kerugian Diprediksi Capai Rp 19,4 Miliar (Fire Gedebage Market, The Loss is Predicted to Reach Rp19.4 Billions). Available online at https://regional.kompas.com/read/2015/07/21/11180561/Kebakaran.Pasar.Gedebage.Kerugi an.Diprediksi.Capai.Rp.19.4.Miliar, Accessed on May 10, 2020

[38] Kompas, 2018. Kerugian Sementara Kebakaran Pasar Gedebage Bandung Rp 6 Miliar Rupiah (Temporary Loss in Bandung Gedebage Market Fire of Rp. 6 Billion). Available online at https://bandung.kompas.com/read/2018/07/16/16144021/kerugian- sementarakebakaran-pasar-gedebage-bandung-rp-6-miliar?page=all, Accessed on May 10, 2020

[39] Tribun Jabar, 2018. Pasar Gede Bage Terbakar, Diduga dari Arus Pendek Listrik (Gede Bage Market Fire, allegedly From Short Circuit). Available online at https://jabar.tribunnews.com/2018/07/15/pasar-gede-bage-terbakar-diduga-dari-arus-pendeklistrik,

Accessed on May 10, 2020

[40] Liputan6, 2018. Asap Muncul dari Sampah, 300 Kios Pasar Gede Bage Bandung Ludes Terbakar (Smoke Came Out from Trash, 300 Stall Gede Bage Market Bandung Burned Down). Available online at https://www.liputan6.com/regional/read/3635599/asap- munculdari-sampah-300-kios-pasar-gedebage-bandung-ludes-terbakar\#, Accessed on May 10, 2020

[41] Dinas Pemadam Kebakaran Kota Semarang (Fire Department of Semarang City), 2020.

[42] Fitri, M. E., and Sufianto, H.: Studi Tingkat Keandalan Keselamatan Kebakaran Pasar Andir Kota Bandung (Reliability Study of Fire Safety in Andir Market, Bandung City). pp. 1-12 
(2018)

[43] Muhammad, K. W. I., and Sufianto, H.: Tingkat Keselamatan Pasar Tradisional dari Bahaya Kebakaran (studi kasus Pasar Kepanjen) (Safety Level of Traditional Markets from Fire Dangers (Case Study in Kepanjen Market)) . pp. 1-9 (2018)

[44] Adelberty, M.: Analisis Kualitas Pelayanan Dinas Pemadam Kebakaran Kota Surabaya (Analysis of Service Quality of the Surabaya City Fire Department). Jurnal Penelitian Administrasi Publik. Vol. 2, pp. 216-223 (2016)

[45] Medcom, 2015. 12 Kios di Pasar induk Caringan Ludes Terbakar (12 Stall in Caringan Market Burned), Available online at https://nusantara.medcom.id/jawabarat/peristiwa/GNGl3Dlb-12-kios-di-pasar-induk-caringin-ludes-terbakar, Accessed on May 10, 2020

[46] Republika, 2015. Kebakaran Pasar Pelita Sukabumi Akibat Konsleting (Pelita Market Sukabumi Fire Due to Short Circuit). Available online at https://www.republika.co.id/berita/nasional/daerah/15/09/25/nv88t1282 -kebakaran-pasarpelita-sukabumi-akibat- konsleting, Accessed on May 10, 2020

[47] BPBD Provinsi DKI Jakarta, 2020. Indeks Berita Bencana: Kebakaran (Disasters News Index: Fire). Available online at https://bpbd.jakarta.go.id/news/category/kbr\#, Accessed on May 10, 2020

[48] Berita Jakarta, 2017. Kerugian Kebakaran Pasar Induk Kramat Jati Diperkirakan Capai Rp 9 M (Fire Loss in Kramat Jati Central Market was estimated to reach Rp. 9 Billion). Available online at http://m.beritajakarta.id/read/45861/kerugian-kebakaran-pasar-induk- kramat-jatidiperkirakan-capai-rp-9-m, Accessed on May 10, 2020

[49] Tribun News, 2017. Dalam Setahun Pasar Sorowako Sudah 2 Kali Terbakar (Within a year, Sorowako Market has been Burned Twice). Available online at https://www.tribunnews.com/regional/2017/02/23/dalam-setahun-pasar-sorowako-sudah-2kali-terbakar,

Accessed on May 10, 2020

[50] Tribun Lutim, 2017. Ini Penyebab Kebakaran Pasar Sorowako Luwu Timur (These are the Causes of Fires in the East Luwu Sorowako Market). Available online at https://makassar.tribunnews.com/2017/02/23/ini-penyebab-kebakaran-pasar-sorowakoluwu-

timur, Accessed on May 10, 2020

[51] Kompas, 2017. Pasar Semin Gunungkidul Kebakaran, 8 Kios Terbakar (Semin Market Gunung Kidul Fire, 8 Stall Burned). Available online at https://regional.kompas.com/read/2017/09/09/12142551/pasar-semin-gunungkidulkebakaran-8-kios-terbakar,

Accessed on May 10, 2020

[52] Sorot Gunung Kidul, 2017. Gas Meledak, Kios Pasar Semin Ludes Terbakar (Exploded Gas, Semin Market Stall Burned). Available online at http://gunungkidul.sorot.co/berita94290-gas-meledak-kios-pasar-semin-ludes-terbakar.html, Accessed on May 10, 2020

[53] Media Indonesia, 2017. Kerugian Kebakaran Pasar Atas Rp 1,5 T (Atas Market Fire Losses Rp 1,5 T). Available online at https://mediaindonesia.com/read/detail/129736 kerugian-kebakaran-pasar-atas-rp1-5-t.html, Accessed on May 10, 2020

[54] Detik News, 2017. Korsleting Listrik Penyebab 100 Kios Pasar Pasrepan Ludes Terbakar (Shorted Electricity Causes 100 Stall Pasrepan Market Burned). Available online at https://news.detik.com/berita-jawa-timur/d-3523299/korsleting-listrik-penyebab-100- kiospasar-pasrepan-ludes-terbakar/komentar, Accessed on May 10, 2020

[55] Detik News, 2017. 100 Kios Ludes, Kerugian Kebakaran Pasar Pasrepan Rp 1,6 Miliar (100 Burned Stall, Pasrepan Market Fire Losses Rp 1,6 Billion). Available online at https://news.detik.com/berita-jawa-timur/d-3523176/100-kios-ludes-kerugian-kebakaranpasar-pasrepan-rp-16-miliar/komentar, Accessed on May 10, 2020

[56] Pantura Post, 2018. Pasar Wiradesa Pekalongan Ludes Terbakar, Kerugian Ditaksir Capai Rp 7 Miliar (Wiradesa Pekalongan Market Burned, Estimated Loss Rp 7 Billion). Available online at https://panturapost.com/pasar-wiradesa-pekalongan-ludes-terbakar- kerugian- 
ditaksir-capai-rp-7-miliar/, Accessed on May 10, 2020

[57] Berita Jakarta, 2019. Kerugian Akibat Kebakaran Pasar Malaka I Rorotan Diperkirakan Rp 50 Juta (Estimated Losses Due to Fire Malaka I Rorotan Market Rp 50 Million). Available online at http://www.beritajakarta.id/read/65068/kerugian-akibat-kebakaran- pasar-malakai-rorotan-diperkirakan-rp-50-juta\#.Xrj9OmgzbIV, Accessed on May 11,2020

[58] Tribun Jakarta, 2019. 16 Kios di Pasar Eviles Penjaringan Habis Terbakar (16 Stall at Eviles Penjaringan Market Burned). Available online at https://jakarta.tribunnews.com/2019/01/07/16 -kios-di-pasar-eviles-penjaringan-habisterbakar, Accessed on May 11, 2020

[59] Republika, 2019. Kerugian Akibat Kebakaran Pasar Lawang Diperkirakan Rp 9 M (Estimated Losses Due to Fire Lawang Market Rp 9 Billion). Available online at https://nasional.republika.co.id/berita/nasional/daerah/pq5kpt414/kerugian-akibatkebakaran-pasar- lawang-diperkirakan-rp-9-m, Accessed on May 11, 2020

[60] Radar Banyumas, 2019. Kios Pasar Patemon Terbakar (Stall Patemon Market Burned). Available online at https://radarbanyumas.co.id/kios-pasar-patemon-terbakar/, Accessed on May 11, 2020

[61] Detik News, 2019. Kebakaran Pasar Kosambi Bandung Telan Kerugian Rp 20 Miliar (Estimated Losses Fire Kosambi Market Bandung until Rp 20 Billion). Available online at http://news.detik.com/berita-jawa-barat/d-4581035/kebakaran-pasar-kosambi- bandungtelan-kerugian-rp-20-miliar, Accessed on May 11, 2020

[62] Radar Solo, 2019. Kerugian Kebakaran Pasar Nglangon Capai Rp 1 Miliar (Estimated Losses Nglangon Market Until Rp 1 Billion). Available online at https://radarsolo.jawapos.com/read/2019/10/02/158728/kerugian-kebakaran-pasar-nglangoncapai-rp-1- miliar, Accessed on May 11, 2020

[63] Tribun Jogja, 2019. Kerugian Capai Rp 3 Miliar Akibat Kebakaran Pasar Mungkid, pemerintah Bakal Bangun Pasar Darurat (Estimated Losses Fire Mungkid Market Until Rp 3 Billion, The Government will Build an Emergency Market). Available online at https://jogja.tribunnews.com/2019/10/18/kerugian-capai-rp-3-miliar-akibat-kebakaran pasarmungkid-pemerintah-bakal-bangun- pasar-darurat, Accessed on May 11, 2020

[64] Suara Jatim, 2019. Pasar Ngunut Terbakar, Kerugian Diperkirakan Mencapai Rp 50 Miliar (Ngunut Market Burned, Estimated Losses Until Rp 50 Billion). Available online at https://jatim.suara.com/read/2019/11/09/171025/pasar-ngunut-terbakar-kerugian-

diperkirakan-mencapai-rp-50-miliar, Accessed on May 11, 2020

[65] Sindo News, 2019. Pasar Baros Serang Ludes Terbakar, Kerugian Capai Rp10 Miliar (Baros Market Serang Burned, Estimated Losses Until Rp 10 billion). Available online at https://daerah.sindonews.com/berita/1457827/174/pasar-baros-serang-ludes-terbakarkerugian-capai-rp10-miliar, Accessed on May 11,2020

[66] Liputan6, 2019. Ini Dugaan Penyebab Pasar Bendul Merisi Surabaya Terbakar (This is the Alleged Cause of Bendul Merisi Market in Surabaya Burning). Available online at https://surabaya.liputan6.com/read/4112559/ini-dugaan-penyebab-pasar-bendul- merisisurabaya-terbakar\#, Accessed on May 11, 2020

[67] Detik News, 2019. Kebakaran Pasar Guntur Garut Diduga Akibat Korsleting Listrik (Causes of fire Guntur Market Garut by Electrical Short Circuit). Available online at https://news.detik.com/berita-jawa-barat/d-4791365/kebakaran-pasar-guntur-garut- didugaakibat-korsleting-listrik, Accessed on May 11, 2020

[68] Oke News, 2020. Pasar Porda Juwana Terbakar Penyebabnya Diduga Arus Pendek (Causes of Fire Porda Juwana Market by Short Circuit). Available online at https://news.okezone.com/read/2020/05/09/512/2211641/pasar-porda-juwana-terbakarpenyebabnya- diduga-arus-pendek, Accessed on May 11, 2020

[69] Pati News, 2020. Kronologi Kebakaran Pasar Porda Juwana Pati, Kerugian Ditaksir 2 Milyar (Chronology of Porda Juwana Pati Market Fire, Estimated Losses 2 Billion). Available online at https://www.patinews.com/kronologi-kebakaran-pasar-porda-juwanapati-kerugian-ditaksir-2-milyar/, Accessed on May 10, 2020

[70] Saibumi, 2020. Pasar Wayjepara Lampung Timur Terbakar, Puluhan Los Pedagang Sayur 
Ludes (Wayjepara Lampung Timur Market Burned, Dozens of Los Vegetable Traders were on Fire). Available online at https://www.saibumi.com/artikel-100586-pasarwayjepara-lampung-timur-terbakar-puluhan-los-pedagang-sayur-ludes.html, Accessed on May 10,2020

[71] Lampung77, 2020. 210 Kios Pasar Way Jepara Lampung Timur Terbakar, Kerugian Rp 2, 5 Miliar (210 Way Jepara Lampung Timur Market Stall Burned, Estimated Losses Rp 2,5 Billion). Available online at https://www.lampung77.com/210-kios-pasar-way- jeparalampung-timur-terbakar-kerugian-rp-25-miliar/, Accessed on May 10, 2020

[72] Suara Jatim, 2020. Pasar Lodoyo Blitar Terbakar, Api Merembet dari 1 Kios ke Kios Lainnya (Lodoyo Blitar Market Burned, Fire Spreads from 1 Stall to Another Stall). Available online at https://suarajawatimur.com/2020/04/04/pasar-lodoyo-blitar-terbakarapi-merembet-dari-1-kios-ke-kios-lainnya/, Accessed on May 11, 2020

[73] Rahardjo, H.A., and Prihanton, M.: The Most Critical Issues and Challenges of Fire Safety for Building Sustainability in Jakarta. Journal of Building Engineering. Vol. 29, pp. 1-10 (2020)

[74] Adventus, M.R., Soepandji, B.S., Abidin, I.S., and Trigunarsyah, B.: Framework of Performance Based Fire Safety Design

Bangunan Tinggi Perkantoran di DKI Jakarta. Pp. 1-6 (2005)

[75] Rodrigues, E.E.C., Rodrigues, J.P.C.,, and Filho, L.C.P.S.: Comparative Study of Building Fire Safety Regulations in Different Brazilian States. Journal of Building Engineering. Vol. 10, pp. 102-108 (2017)

[76] Qianli, M., and Wei, G.: Discussion on the Fire Safety Design of a High-Rise Building. Procedia Engineering. Vol. 45, pp. 685- 689 (2012)

[77] Nurmayadi, D., and Huseiny, M.S.A.: Peningkatan Kualitas Keandalan Sarana dan Prasarana Sistem Proteksi Kebakaran Pasar Tradisional di Kota Tasikmalaya (Improving the Quality of Reliability of Facilities and Pre-Facilities of Traditional Market Fire Protection Systems in Tasikmalaya City). Jurnal Arsitektur ARCADE Vol. 2, pp. 163-169 (2018)

[78] Aliyu, I., and Mustapha, D.I.: An Evaluation of Fire Disaster Safety Measure in Sokoto Metropolis. Sokoto Journal of the Social Sciences. Vol. 8, pp. 46-59 (2018)

[79] Nining, W.O., Widayati, W., and Harimuddin, J.: Kajian Risiko Bencana Kebakaran Permukiman Di Kecamatan Mandonga Kota Kendari (Resettlement Fire Disaster Risk Study in Mandonga District, Kendari City). Jurnal Geografi Aplikasi Dan Teknologi. Vol. 1, pp. 31-44 (2017)

[80] Li, S., Tao, G., and Zhang, L.: Fire Risk Assessment of High-Rise Buildings Based on GrayFAHP Mathematical Model. Procedia Engineering. Vol. 211, pp. 395-402(2018)

[81] Anam, A.K., and Winarni, S., Handes, L. Gambaran Kesiapsiagaan Pedagang Pasar dalam Penanggulangan Bencana Kebakaran di pasar Legi Kota Blitar (Disaster Nursing Research) (The Description of Marketeer Preparedness of Fire Disaster Management of Legi Market Blitar city, Disaster Nursing Research). Jurnal Ners dan Kebidanan. Vol. 3, pp. 278285(2016)

[82] Sujatmiko, W., Dipojono, H.K., Soelami, F.X.N., and Soegijanto.: Performance-Based Fire Safety Evacuation in High-Rise

Building Flats in Indonesia - A Case Study in Bandung. Procedia Environmental Sciences. Vol. 20, pp. 116-125 (2014)

[83] Setiawan, M.F., Purnomo, A., and Santoso, E.B.: Kemampuan Bangunan Pasar Tradisional Sampangan dalam Mengantisipasi Bahaya Kebakaran (Studi Kasus Pasar Sampangan di Semarang, Central Java) (The Ability of Building a Traditional Sampangan Market in Anticipating Fire Dangers (Case Study of the Sampangan Market in Semarang, Central Java)) . Jurnal Kompetensi Teknik. Vol. 11, pp. 1-13 (2019)

[84] Santosa, S., Rochadi, M.T., Suroso, Suwarto, and Mawardi.: Penentuan Prioritas Perbaikan Gedung Menggunakan Metode AHP dari Sudut Pandang Tenant (Determination Of Repair Priority Building Using AHP Method From Tenant Viewpoint). Wahana Teknik Sipil. Vol. 24, pp. 89-103 (2019)

[85] Januandari, M.U., Rachmawati, T.A., and Sufianto, H.: Analisa Risiko Bencana Kebakaran 
Kawasan Segiempat Tunjungan Surabaya (Fire Disaster Risk Analysis in Tunjungan Quadrilateral in Surabaya). Jurnal Pengembangan Kota. Vol. 5, pp. 149-158 (2017)

[86] Nuswantoro, W.: Analisis Jenis Kerusakan pada Bangunan Perumahan (Studi Kasus pada Perumahan Pondok Pasir Mas Palangka Raya) (Analysis of Damage Types in Housing Buildings (Case Study on Pondok Pasir Mas Palangka Raya Housing)) . Jurnal Rekayasa Rancang Bangun. Vol. 11, pp. 1-14 (2010)

[87] Setiaji, K., and Fatuniah, A.L.: Pengaruh Modal, Lama Usaha dan Lokasi Terhadap Pendapatan Pedagang Pasar Pasca Relokasi (Influence of Capital, Length of Business and Location on Trader Income after Relocation). Jurnal Pendidikan Ekonomi Dan Bisnis (JPEB). Vol. 6, pp. 1-14 (2018)

[88] Zheng-yang, AN., and Bin, L.: Chinese Historic Buildings Fire Safety and Countermeasure. Procedia Engineering. Vol. 52, pp. 23-26 (2013)

[89] Nimlyat, P.S., Audu, A.U., Ola-Adisa, E.O., and Gwatau, D.: An Evaluation of Fire Safety Measures in High-Rise Buildings in Nigeria. Sustainable Cities and Society. Vol. 35, pp. 774-85 (2017)

[90] Wang, Q., and Zhang. C.: Fire Safety Analysis of Building Partition Wall Engineering. Procedia Engineering. Vol. 211 , pp. 747- 754 (2018)

[91] Cowlard, A., Bittern, A., Abecassis-Empis, C., and Torero, J.: Fire Safety Design for Tall Buildings. Procedia Engineering. Vol. 62, pp. 169-181(2013)

[92] Östman, B., Brandon, D., and Frantzich, H.: Fire Safety Engineering in Timber Buildings. Fire Safety Journal. Vol. 91, pp. 11-20 (2017)

[93] Pynkyawati, T., Wahadamaputera, S., Adiwibowo, F., Lestari, R.R., and Septaningsih, D.P.: Kajian Desain Sirkulasi Ruang Dalam sebagai Sarana Evakuasi Kebakaran pada Bangunan Hotel Carrcadin Bandung (Study of Indoor Circulation Design as a Means of Fire Evacuation at Carrcadin Hotel Building Bandung). Jurnal Itenas Rekayasa Institut Teknologi Nasional. Vol. XIII, pp. 196-206 (2009)

[94] Wahyono, B.: Analisis Faktor-faktor yang Mempengaruhi Pendapatan Pedagang di Pasar Bantul Kabupaten Bantul (Analysis of Factors that affect Trader Income in Bantul Market, Bantul Regency). Jurnal Pendidikan dan Ekonomi. Vol. 6, pp. 388 -399(2017)

[95] Adventus, R.M.: Key Factors Affecting to Construction Insurance on Fire Safety on High Rise Buildings In Indonesia. Law

Review, Fakultas Hukum Universitas Pelita Harapan. Vol. 1, pp. 122-135 (2001)

[96] Choi, J., Jeon, G., and Hong, W.: The Introduction of a USN-Based Fire Protection Model: Regarding the Seomun Traditional Market in Daegu, Korea. WIT Transactions on The Built Environment. Vol. 94, pp. 223 -232 (2007)

[97] Peng, L., Ni, Z., and Huang, X.: Review on the Fire Safety of Exterior Wall Claddings in High-Rise Buildings in China. Procedia Engineering. Vol 62, pp. 663-670 (2013)

[98] Liu, F., Zhao, S., Weng, M., and Liu, Y.: Fire Risk Assessment for Large-Scale Commercial Buildings Based on Structure Entropy Weight Method. Safety Science. Vol. 94, pp. 26-40 (2017)

[99] Sun, X., and Luo, M.: Fire Risk Assessment for Super High-Rise Buildings. Procedia Engineering. Vol. 71, pp. 492-501 (2014)

[100] Azad, T.A., Hasan, I., Saha, M.K., Ahmmed, R., Moni, S.J., and Kabir M.H.: Risk of Fire Disaster: Consequences on Industry Sectors in Bangladesh. International Journal of Energy and Sustainable Development. Vol. 13, pp. 52 -63 (2018) 